\title{
The analysing of fat content in cheddar cheese fermented with Citrus reticulata Blanco crude flowers in different concentrations as a healthy diet
}

\section{Farklı konsantrasyonlarda Cittrus reticulata Blanco çiçekleri ile fermente edilmiş çedar peynirindeki yağ içeriğinin analizi}

\author{
Betüll Özdemir ${ }^{1 *}$, Usman Mir Khan², Zeliha Selamoğlü ${ }^{3}$
}

Department of Cardiology, Faculty of Medicine, Nigde Omer Halisdemir University, Campus, Nigde, Turke

Department of Dairy Technology, Faculty of Animal Production and Technology, University of Veterinary and Animal Sciences, Lahore, Pakistan ${ }^{3}$ Department of Medical Biology, Faculty of Medicine, Nigde Omer Halisdemir University, Campus, Nigde, Turkey

Corresponding author: Betül Özdemir, MD, Department of Cardiology, Faculty of Medicine, Nigde Omer Halisdemir University, Campus, Nigde, Turkey

E-mail: betulozaltun@ohu.edu.tr

Received/Accepted: November 04, 2020 / June 21, 2021

Conflict of interest: There is not a conflict of interest.

\section{SUMMARY}

Objective: There is strong evidence that a high fat intake causes cholesterol increases in human body. We all know high cholesterol levels causes cardiovascular diseases. This study was aimed to investigate the fat content in cheddar cheese which coagulated with Citrus reticulata Blanco crude flowers extracts (CFE) at four different concentrations (1, 2, 3 and 4\%, v/v). Method: Flowers of Citrus reticulata Blanco were collected during blossom from Sargodha District nurseries. Buffalo milk was used for preparation of Cheddar cheese. A control sample ( $\left.\mathrm{T}_{0}\right)$ was coagulated with $0.002 \%$ rennet (Rennet strength is 20 International Milk-Clotting Units, $\mathrm{IMCU} / \mathrm{mL}$ ) at $33^{\circ} \mathrm{C}$ for 45 minutes and it was obtained from Danisco Dairy Cultures (Paris, France) while the other four samples were coagulated using Citrus reticulata Blanco $\mathrm{CFE}$ at different concentrations of $1 \%(\mathrm{~T} 1), 2 \%(\mathrm{~T} 2), 3 \%(\mathrm{~T} 3)$ and $4 \%(\mathrm{~T} 4)(\mathrm{v} / \mathrm{v})$ at $33^{\circ} \mathrm{C}$ for 45 minutes. Results: Results of statistical analysis of variance showed significant differences $(p=0.0001)$ among different concentration of CFE for Cheddar cheese fat contents. The cheese prepared from using $1 \%$ and $4 \%$ CFE cheese have higher fat contents while CFE cheese prepared with $2 \%$ and $3 \%$ have lower fat contents and less than control sample prepared with rennet.

Conclusions: In this study, we determined the amount of fat in cheddar, which was fermented with citrum flower according to the rennet. In the future this study can be a guide to consume healty food and improving human health.

Keywords: Cheddar cheese, Citrus reticulata Blanco, dietary cholesterol, health-promoting benefit, low-fat cheddar cheese
(D) Betül Özdemir
(D) Usman Mir Khan
(D) Zeliha Selamoğlu

ORCID IDs of the authors: B.Ö. 0000-0003-4725-9522 U.M.K. 0000-0002-4950-5769 Z.S. 0000-0001-9056-6435 
Amaç: Yüksek yağ alımının insan vücudunda kolesterol artışına neden olduğuna dair güçlü kanıtlar vardır. Yüksek kolesterol seviyelerinin kardiyovasküler hastalıklara neden olduğu bilinmektedir. Bu çalışmada Citrus reticulata Blanco çiçek özleri (CFE) ile dört farklı konsantrasyonda (\% 1, 2, 3 ve 4, v / v) koagüle edilen çedar peynirindeki yağ içeriğinin incelenmesi amaçlanmıştır.

Yöntem: Narenciye çiçekleri, Sargodha Bölgesi fidanlıklarından çiçeklenme sırasında toplandı. Bufalo sütü, çedar peynirinin hazırlanmasında kullanılmıştır. Bir kontrol numunesi (T0)\% 0,002 rennet (Rennet gücü 20 Uluslararası SütPıhtılaşma Birimi, IMCU / mL) ile $33^{\circ} \mathrm{C}^{\prime}$ de 45 dakika koagüle edildi ve Danisco Dairy Cultures'tan (Paris, Fransa), diğeri 4 numune Citrus reticulata Blanco CFE kullanılarak $33^{\circ} \mathrm{C}^{\prime} \mathrm{de} 45$ dakika boyunca\% 1 (T1),\% 2 (T2),\% 3 (T3) ve\% 4 (T4) (v/ v) farkl1 konsantrasyonlarda koagüle edildi.

Bulgular: İstatistiksel varyans analizi sonuçları, çedar peyniri yağ içerikleri için farklı CFE konsantrasyonları arasında önemli farklılıklar ( $\mathrm{p}=0.0001)$ gösterdi. \% $1 \mathrm{ve} \% 4$ CFE peynirlerinden hazırlanan peynirler daha yüksek yağ içeriğine sahipken, \% 2 ve\% 3 ile hazırlanan CFE peynirler daha az yağ içeriğine ve peynir mayası ile hazırlanan kontrol numunesine göre daha azdır.

Sonuç: Bu çalışmada süt mayasına göre narenciye çiçeği ile fermente edilen çedar peyniri içindeki yağ oranını belirledik. Gelecekte bu çalışma, sağlıklı gıda üretmek, tüketmek ve insan sağlığını iyileştirmek için bir rehber olabilir.

Anahtar sözcükler: Citrus reticulata Blanco, çedar peyniri, kolesterol, narenciye çiçeği

\section{INTRODUCTION}

Cardiovascular disease (CVD) is a leading cause of death in the whole world. Atherosclerosis, a chronic inflammation, is often the cause of CVD. In pathophysiology, atherosclerosis occurs with the accumulation of cholesterol and fibrous tissues in the arterial walls, and as a result of this accumulation, partial or total occlusion occurs ${ }^{1}$. There are many risks for CVD that can be changed and cannot be changed. Risks that cannot be modified can be listed as age, gender, and family history. In addition, the modified risks; smoking, diabetes mellitus, dyslipidemia, hypertension, sedentary life, lifestyle and diet can be listed as known. The fact that CVD can be prevented in several different ways, for example, by statins and antihypertensive drug usage, smoking cessation, or other lifestyle modifications, is a reflection of its multifactorial basis. In CVDs the diet plays a key role. Good cardiovascular health status is related to a balanced energy intake including whole-grain foods, legumes, seafood and fish, and rich content in fruits and vegetables and low intake of processed food and red meat, sugar added foods or beverages and refined grains. Polyunsaturated fatty acid ratios in diets are very important for cardiovascular health ${ }^{2,3}$.

Dairy products are a major source of saturated fats, which have been presumed to adversely affect blood lipids and increase cardiovascular disease and mortality. In some studies, reducing consumption of whole milk products is recommended to prevent cardiovascular diseases ${ }^{4}$. Besides dairy products and dairy fat also contain potentially beneficial compounds; specific aminoacids, medium-chain and odd-chain saturated fats, milk fat globule phospholipids, unsaturated and branched-chain fats, natural trans fats, vitamin $\mathrm{K} 1$ and $\mathrm{K} 2$ and calcium ${ }^{5}$. Another fact that high intakes of saturated fats have been associated with an increase in LDL cholesterol concentrations an established risk factor in the development of $\mathrm{CVDs}^{6}$. Cheese is an important food for human health. It is rich in protein, minerals (Calcium and Phosphorous) and fat soluble vitamins ${ }^{7}$. It has become an important component of balance diet because of its high protein and calcium contents. In the past decade, cheese has become one of the most widely used food ingredients. Cheese is valued for its long life and differs from country to country in colors, flavor, and texture. Cheddar cheese (a hard ripened cheese) is produced by acidification and concentration of milk following curd formation with milk clotting enzyme ${ }^{8}$. Coagulation of milk by the action of better proteases on milk proteins is a major step to have better curd and rheology in cheese production technology. Processing conditions such as gelation temperature, concentration of coagulant, $\mathrm{pH}$ and cutting time also affects rheology of cheese ${ }^{9}$. The conversion of milk to curd occurs by specific hydrolysis of the peptide bond in the casein, which leads to accumulation of casein with calcium and proteolysis of milk proteins ${ }^{10}$. Traditionally, yeast is obtained from young calves. Due to the small amount of rennet obtained from young calves, microbial rennet obtained from bacterial, fungal and genetically modified microorganisms used in cheese production ${ }^{11}$. Several alternative proteases obtained from different vegetable and fruit sources (e.g., kiwi, melon and papaya), roots (e.g., ginger), latex (e.g., papaya fruit and sodom apple) and flowers (e.g., Citrus aurantium, Cynara cardunculus and Centaurea calcitrapa), have been recommended as milk-clotting agents in cheese processing ${ }^{12-14}$. Additionally, these plant extracts 
have unique functional properties in flavor and texture, and will lead to innovative applications in new product development ${ }^{15}$. Citrus flowers are known for their pleasant, highly desirable aroma and their essential oils ${ }^{16}$. Kinnow has proteolytic enzyme which can be obtain from generative organs of flowering plants ${ }^{17}$. Plant tissues present in Kinnow contains a wide range of proteins varying in functional properties. Current study was designed to develop the Kinnow crude flowers extract as a new source of milk-clotting enzyme in cheese production technology. Rennet production is time consuming and costly, so CFE was used as economical and potential source for milk coagulation in Cheddar cheese production. CFE has typical aroma and flavor, it also contains citrase enzyme which has the activity to coagulate the milk. Centrifugation of extract with Tris-HCL buffer leads to the activation of citrase enzyme ${ }^{18}$.

Low-fat cheeses were started to be consumed frequently by some countries due to their health benefits ${ }^{19}$. Although some new technologies were used to improve flavor, texture, and functionality of cheese, research has mainly focused on soft lowfat and fresh cheeses ${ }^{20}$. Low-fat, semi-hard, and hard ripened cheeses have not been well studied. Generally, manufacturing procedures developed to improve low-fat, semi-hard, and hard ripened cheeses include processing techniques, use of additives, and starter culture selection ${ }^{21-23}$. However, technological improvements to cheesemaking processes do not necessarily apply to all cheese plants or cheese types, and they may incur financial costs. The use of additives, such as emulsifying and thickening agents, could improve cheese texture, but they might have adverse effects on flavor formation ${ }^{24}$. Cheddar cheese ripening is a complicated microbiological and biochemical transformation involving glycolysis, lipolysis and proteolysis $^{25}$. All of these biochemical processes contribute to the overall structure change during maturation. However, the texture, flavor and physico-chemical properties of cheese are still largely governed by fat. The state of fat is also important in determining the complex sensory properties of Cheddar cheese ${ }^{26}$. The taste, hardness and content ratio of cheddar cheese may vary depending on the yeast type. In this study, we studied the fat content of cheddar cheese fermented with citrus.

\section{MATERIAL AND METHODS}

\section{Procurement of samples:}

Flowers of Citrus reticulata Blanco were collected during blossom periods from Sargodha. Flowers were collected and stored in freezer in food grade bags at $-20^{\circ} \mathrm{C}$ to keep them fresh. Five liters of buffalo milk was used for each treatment. Buffalo milk was procured from the Dairy Animals Training and Research Center, UVAS, Ravi Campus, Pattoki.

\section{Experimental Plan:}

Crude Flowers Extract (CFE) was prepared by blending citrus flowers with 5 parts of cold buffer $(20 \mathrm{mmol} / \mathrm{L}$ of Tris- $\mathrm{HCl}$ having $\mathrm{pH}$ 7.20) in an electrical blender for 3 intermittent periods of 15 seconds. The blended sample was filtered by using a cheese cloth and then centrifuged by centrifugal machine having $7500 \mathrm{rpm}$ at $10^{\circ} \mathrm{C}$ for 30 minutes. Then separate the aqueous phase from pallet by gradually pouring in the plastic test tubes. Then aqueous extract was kept in a refrigerator $\left(4^{\circ} \mathrm{C}\right)$ till it is used ${ }^{18}$.

\section{Treatments and Experimental Design:}

A control sample (T0) was coagulated with $0.002 \%$ rennet (Rennet strength is 20 International MilkClotting Units, IMCU $/ \mathrm{mL}$ ) at $33^{\circ} \mathrm{C}$ for 45 minutes and it was obtained from Danisco Dairy Cultures (Paris, France) while the other four samples were coagulated using Citrus reticulata Blanco CFE at different concentrations of $1 \%(\mathrm{~T} 1), 2 \%$ (T2), $3 \%$ (T3) and $4 \%(\mathrm{~T} 4)(\mathrm{v} / \mathrm{v})$ at $33^{\circ} \mathrm{C}$ for 45 minutes (Table 1).

Table 1: Detail of the Experiments

\begin{tabular}{|l|l|l|}
\hline Sr. No. & Treatments & Coagulants with different levels \\
\hline 1 & T0 (Controlled) & Rennet $(0.002 \%)$ \\
\hline 2 & T1 & CFE $(1 \%)$ \\
\hline 3 & T2 & CFE $(2 \%)$ \\
\hline 4 & T3 & CFE $(3 \%)$ \\
\hline 5 & T4 & CFE $(4 \%)$ \\
\hline
\end{tabular}

All treatments were evaluated for 63 days of storage intervals which were as followed:

Storage periods

$$
\begin{aligned}
& \text { S1 }=0 \text { day } \\
& \text { S4 }=21 \text { days } \\
& \text { S7 }=42 \text { days }
\end{aligned}
$$

$$
\begin{aligned}
& \text { S2 }=7 \text { days } \\
& \text { S5 }=28 \text { days } \\
& \text { S8 }=49 \text { days }
\end{aligned}
$$

S3 $=14$ days

S6 $=35$ days

S9 $=56$ days $\mathrm{S} 10=63$ days 


\section{Product development and Storage:}

Buffalo milk (five liters for each treatment) was used for preparation of Cheddar cheese. First milk was pasteurized at $65^{\circ} \mathrm{C}$ for 30 minutes and then cooled at $33^{\circ} \mathrm{C}$ for inoculation. Then all treatments were inoculated with $2 \%$ of starter cultures (Lactococcus lactis subsp. Lactis and Lactococcus lactis subsp. Cremoris). Controlled sample was coagulated with $0.002 \%$ rennet at $33^{\circ} \mathrm{C}$ for 45 minutes and other four samples were coagulated at $38^{\circ} \mathrm{C}$ for 45 minutes by using Citrus reticulata Blanco crude flower extracts (CFE) at different levels of $1 \%, 2 \%, 3 \%$ and $4 \%$. When curd was firm enough, it was cut, stirred and whey drained. Then it was cooked and milled at $38^{\circ} \mathrm{C}$ and turned the blocks up and down to separate more whey from the curd.

This block of cheese was kept warm and then cheddaring of block leads to acid development. Salting was done at the rate of $2.5 \%$ then by pressing the cheese blocks whey was removed. Storage and ripening of cheese was done at $10^{\circ} \mathrm{C}$ for 2 to 3 months ${ }^{27}$. Waxing of Cheddar cheese was done to preserve it from molds and other contaminants.

\section{Fat contents measurement:}

Fat percentage of Cheddar cheese samples were measured by Gerber method. Cheddar cheese samples were heated up to $40^{\circ} \mathrm{C}$ in water bath and then cooled to $20^{\circ} \mathrm{C} .10 \mathrm{~mL}$ of sulfuric acid $(90 \%)$ was added into butyrometer. 2.5 grams of Cheddar cheese sample was poured into butyrometer. Then $1 \mathrm{~mL}$ fat free Iso-amyl alcohol was added in butyrometer and mixed thoroughly after placing a stopper on butyrometer. The butyrometer was kept in Gerber centrifuge machine. Centrifugation was done at $1100 \mathrm{rpm}$ for 5 minutes. When machine stopped the butyrometer was taken out and reading was noted from scale of butyrometer. This reading was the fat percentage of Cheddar cheese.

\section{Statistical Examination:}

The collected data were analyzed by using one way Analysis of Variance (ANOVA) techniques under Completely Randomized Design (CRD) (Steel et al. 1987). Duncan's Multiple Range (DMR) Test was used for significant difference comparisons in this study (SAS 9.1 Statistical Software).

\section{RESULTS}

Results of statistical analysis showed significant differences $(\mathrm{P}=0.0001)$ among different concentration of CFE for Cheddar cheese fat $(\%)$ after 63 days of storage. The cheese prepared from using $1 \%$ and $4 \%$ CFE cheese have higher fat contents while CFE cheese prepared with $2 \%$ and $3 \%$ have lower fat contents and less than control sample prepared with rennet (Table 2). The results are showed in figure 1 .

Table 2: Effect of CFE and storage periods on Fat \% value of Cheddar cheese

\begin{tabular}{|c|c|c|c|c|c|c|c|c|c|c|}
\hline Treatments & Week 0 & Week 1 & Week 2 & Week 3 & Week 4 & Week 5 & Week 6 & Week 7 & Week 8 & Week 9 \\
\hline TO & $35.17 \pm 0.17^{\mathrm{a}}$ & $36.17 \pm 0.17^{\mathrm{a}}$ & $36.17 \pm 0.17^{a}$ & $37.00 \pm 00^{\mathrm{a}}$ & $37.17 \pm 0.17^{\mathrm{a}}$ & $37.34 \pm 0.17^{\mathrm{a}}$ & $36.17 \pm 0.17^{\mathrm{a}}$ & $35.17 \pm 0.17^{\mathrm{a}}$ & $35.17 \pm 0.17^{\mathrm{a}}$ & $35.67 \pm 0.34^{\mathrm{a}}$ \\
\hline T1 & $35.17 \pm 0.17^{\mathrm{a}}$ & $35.17 \pm 0.17^{b}$ & $34.17 \pm 0.17^{\mathrm{c}}$ & $36.17 \pm 0.17^{b}$ & $35.00 \pm 00^{\mathrm{b}}$ & $34.17 \pm 0.17^{\mathrm{c}}$ & $34.84 \pm 0.17^{b}$ & $33.67 \pm 0.34^{b}$ & $34.67 \pm 0.34^{\mathrm{ab}}$ & $34.84 \pm 0.44^{\mathrm{ab}}$ \\
\hline $\mathrm{T} 2$ & $34.34 \pm 0.33^{\mathrm{b}}$ & $35.17 \pm 0.17^{b}$ & $35.00 \pm 00^{b}$ & $34.17 \pm 0.17^{\mathrm{d}}$ & $34.17 \pm 0.17^{\mathrm{c}}$ & $35.00 \pm 00^{b}$ & $34.00 \pm 00^{c}$ & $33.84 \pm 0.44^{\mathrm{ab}}$ & $33.50 \pm 0.50^{c}$ & $34.17 \pm 0.17^{\mathrm{bc}}$ \\
\hline T3 & $35.17 \pm 0.17^{\mathrm{a}}$ & $34.33 \pm 0.17^{\mathrm{c}}$ & $35.17 \pm 0.17^{b}$ & $35.00 \pm 00^{c}$ & $35.17 \pm 0.17^{b}$ & $34.00 \pm 00^{c}$ & $33.00 \pm 00^{\mathrm{d}}$ & $32.50 \pm 0.50^{\mathrm{b}}$ & $32.50 \pm 0.29^{d}$ & $33.17 \pm 0.17^{\mathrm{c}}$ \\
\hline $\mathbf{T 4}$ & $34.17 \pm 0.17^{b}$ & $33.17 \pm 0.17^{\mathrm{d}}$ & $34.17 \pm 0.17^{\mathrm{c}}$ & $36.17 \pm 0.17^{b}$ & $35.00 \pm 00^{\mathrm{b}}$ & $35.17 \pm 0.17^{b}$ & $34.83 \pm 0.17^{b}$ & $33.33 \pm 0.67^{b}$ & $34.00 \pm 00^{\mathrm{cb}}$ & $34.67 \pm 0.44^{\mathrm{ab}}$ \\
\hline
\end{tabular}

* All values are triplicate means of each treatment.

**Different small alphabets showing significant differences among different treatments $(\mathrm{P}<0.05)$

$\mathbf{T}_{\mathbf{0}}=$ Controlled Cheddar cheese with no use of Citrus reticulata Blanco crude flowers extract

$\mathbf{T}_{1}=$ Cheddar cheese prepared with $1 \%$ Citrus reticulata Blanco crude flowers extract

$\mathbf{T}_{\mathbf{2}}=$ Cheddar cheese prepared with $2 \%$ Citrus reticulata Blanco crude flowers extract

$\mathbf{T}_{3}=$ Cheddar cheese prepared with $3 \%$ Citrus reticulata Blanco crude flowers extract

$\mathbf{T}_{4}=$ Cheddar cheese prepared with $4 \%$ Citrus reticulata Blanco crude flowers extract 


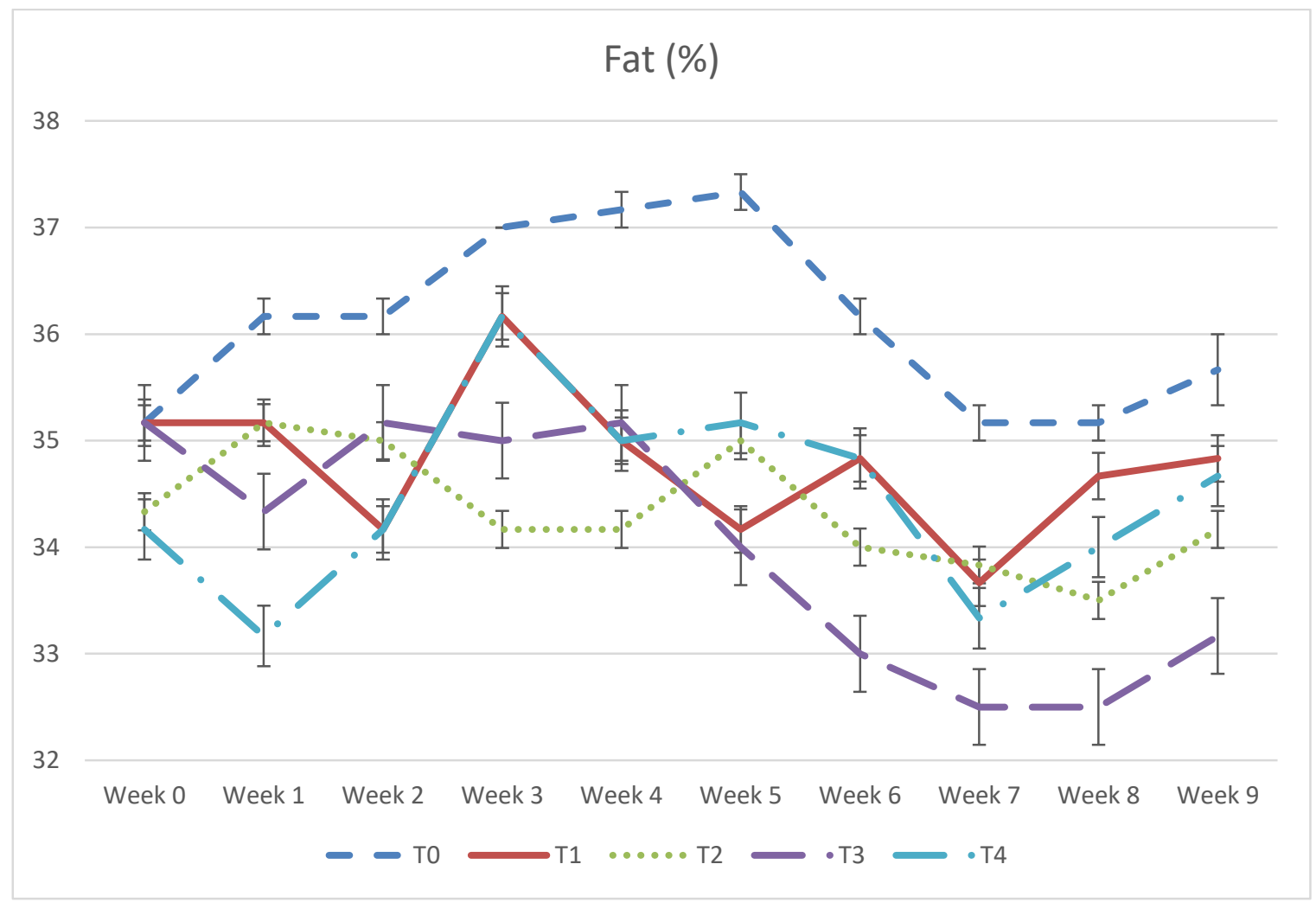

Figure 1: Graphical representation of the effect on fat $\%$ value of CFE coagulated Cheddar cheese with storage period

\section{DISCUSSION}

The aim of this study was to develop Cheddar cheese by using different levels of Citrus reticulata Blanco crude flowers extract (CFE) as coagulant and comparing it with rennet coagulated Cheddar cheese. Fat content of Cheddar cheese were analyzed. In our study cheddar cheese samples were observed for fat contents and the data was recorded. Average fat content of different treatments showed in table 2. Fat was $45 \%$ on dry basis resembling to rennet made Cheddar cheese. The cheese prepared from using $1 \%$ and $4 \%$ CFE cheese showed higher fat contents from 0 to 63 days while CFE cheese prepared with $2 \%$ and $3 \%$ have significant fat contents and less than control sample prepared with rennet. In this study, fat \% showed some variation ranging from $32-37 \%$. The results of this study showed that fat contents of cheese decrease in ripening process from $35 \%$ to $34 \%$ in rennet coagulated Cheddar cheese during ripening process as described by O'Mahony et al. ${ }^{28}$. While 3\% CFE Cheddar cheese showed a decrease in fat percentage up to $33 \%$ after 63 days of storage. Also, this ripening process can be increased by storing cheese at $10^{\circ} \mathrm{C}$. Fat contents lead to a fatty texture of Cheddar cheese, specific aroma and flavor development in Cheddar cheese as described by Singh et al. ${ }^{29}$. Some studies showed a nonsignificant increase in LDL cholesterol with either higher intake of whole-fat dairy or low-fat dairy ${ }^{30}$. Another meta-analysis of small randomised trials showed that compared with tofu or fat-modified cheeses, cheese consumption increased LDL cholesterol concentration by a modest amount ${ }^{31}$. Current dietary guidelines recommend the consumption of two to four servings of fat-free or low-fat dairy. Our data are in agreement with a review of previously published human trials investigating the chronic impact of fatty acid modified butter/dairy products, which indicated a tendency toward a beneficial effect on the fasting cholesterol profile ${ }^{32}$. In another study, there was no significant effect on the concentration, or distribution, of particles within the LDL and HDL subclasses, which may be explained by the differential cardiometabolic health effects of dairy food sources $^{33}$ and the relatively modest differences in saturated fat composition between the intervention products ${ }^{34}$. In a study by Wang et al., Cheddar cheese fermented with exopolysaccharide (EPS) -producing Lactobacillus plantarum JLK0142 is a new approach to improving the low-fat, ripening properties and bioactivity of Cheddar cheese ${ }^{35}$. Lombardi et al. showed that cheddar cheese coalgulated with 
Aspergillus Niger extract had low fat composition from rennet coagulated cheddar cheese ${ }^{36}$.

In the present work, we obtained the results about low fat \% of Cheddar cheese fermented with Citrus reticulata Bianco crude flowers in $\mathrm{T} 3$ concentrations (Cheddar cheese prepared with 3\% Citrus reticulata Blanco crude flowers extract) with 49 and 56 days (7 and 8 weeks) in Storage periods. This result means that healty diet Cheddar cheese fermented with 3\% Citrus reticulata Bianco crude flowers in storage periods during 7 and 8 weeks for the low fat amount. It might be suggested to consume as the more safety dairy food to neutral or reduce risk factors in the development of cardiovascular diseases with Cheddar cheese fermented with Citrus reticulata Bianco crude flowers. High intakes of saturated fatty acids have been associated with an increase in LDL cholesterol concentrations, an established risk factor in the development of cardiovascular diseases and hypertension. Our finding with this study demonsrating that consuming dairy cheese with low fat ratios in diets may provide most beneficial for blood lipid and cardiovascular health.

\section{CONCLUSION AND SUGGESTIONS}

Presently, in producing Cheddar cheese, several alternative proteases obtained from different vegetable and fruit sources such as fruits, roots, latex and flowers have been recommended as rennet coagulant replacer in cheeses processing. As there is now decrease in slaughtering of young calves, natural rennet shortage occurs, so to fill it, sometimes alternates of rennet used in cheese production technology. The present work was designed to implement and introduce the use of Citrus reticulata Blanco crude flower extracts as an economical, easily available and rennet substitute in Cheddar cheese production. Citrus reticulata Blanco crude flower extracts was evaluated for its first time usage as coagulant in Cheddar cheese production and compared with rennet for its fat ratios and also as a safety diet in health reflections such as cardiovascular health. According to the rennet application in our study, differences were observed in the amount of fat in cheddar cheese fermented with citrum flower. The differences in the amount of fat varied according to the amount of coagulant and the fermentation time. It is important to keep the amount of fat optimal for human health. In this study, we determined the amount of fat in cheddar, which was fermented with citrum flower according to the rennet. With this study in the future, it may be beneficial for public health with a diet that is poor in fat. In addition to, it will give a benefit to the cheese industry by introducing a new economical, nutritional and easily available rennet substitute source of milk coagulation. Producing of Citrus reticulata Blanco, for usage as an alternate of rennet and to provide economic benefits. Furthermore, it will open new ways for researchers to find out the characterization of extract and enzyme of citrum flower to obtain the healty dairy foods.

\section{Acknowledgements:}

The authors are grateful to Department of Dairy Technology Postgraduate Laboratory of University of Veterinary and Animal Sciences, Pakistan for providing research facilities and their excellent technical assistance.

\section{REFERENCES}

1.Espinola-Klein C, Gori T, Blankenberg S, et al. Inflammatory markers and cardiovascular risk in the metabolic syndrome. Front Biosci (Landmark Ed). 2011;16:1663-74.

2.Benjamin EJ, Blaha MJ, Chiuve SE, et al. Heart Disease and Stroke Statistics-2017 Update: A Report From the American Heart Association. Circulation. 2017;135(10):e146-e603.

3.Fitó M, Melander O, Martínez JA, et al. Advances in Integrating Traditional and Omic Biomarkers When Analyzing the Effects of the Mediterranean Diet Intervention in Cardiovascular Prevention. Int J Mol Sci. 2016;17(9):1469.

4.Alexander DD, Bylsma LC, Vargas AJ, et al. Dairy consumption and CVD: a systematic review and meta-analysis. Br J Nutr. 2016;115(4):737-50.

5.Mozaffarian D, Wu JHY. Flavonoids, Dairy Foods, and Cardiovascular and Metabolic Health: A Review of Emerging Biologic Pathways. Circ Res. 2018;122(2):369-384.

6.Mensink RP, Zock PL, Kester AD, et al. Effects of dietary fatty acids and carbohydrates on the ratio of serum total to HDL cholesterol and on serum lipids and apolipoproteins: a meta-analysis of 60 controlled trials. Am J Clin Nutr. 2003;77(5):114655.

7.Donnelly JE, Sullivan DK, Smith BK, et al. The Effects of Visible Cheese on the Selection and Consumption of Food Groups to Encourage in Middle School Students. J Child Nutr Manag. 2010;34(1).

8.Banks JM. Cheddar-Type Cheese. Hannah Research Institute, Ayr, Elsevier, Science Publication. 2012, UK.

9.Hussain I, Bell AE, Grandison AS. Comparison of the rheology of mozzarella-type curd made from 
buffalo and cows' milk. Food Chem. 2011;128(2):500-4.

10.Kumar A, Grover S, Sharma J, et al. Chymosin and other milk coagulants: sources and biotechnological interventions. Crit Rev Biotechnol. 2010;30(4):243-58.

11.Andren A. Cheese: Rennets and Coagulants. Encyclopedia of Dairy Sciences. $2^{\text {nd }}$ Ed. Springer Publishers, New York. 2011;574-578.

12.Adetunji VO, Salawu OT. West African soft cheese 'wara' processed with Calotropis procera and Carica papaya: A comparative assessment of nutritional values. Afr J Biotechnol, 2008;7(18): 3360-3362.

13.Domsalla A, Melzig MF. Occurrence and properties of proteases in plant latices. Planta Med. 2008;74(7):699-711.

14.Fernandez-Salguero J, Tejada L, Gomez R. Use of powdered vegetable coagulant in the manufacture of ewe's milk cheeses. J Sci Food Agric. 2002;82(4): 464.

15.Harboe M, Broe ML, Qvist KB. The Production, Action and Application of Rennet and Coagulants, Technology of Cheese making. Blackwell Publishing Ltd. 2010;1-45.

16.Jabalpurwala FA, Smoot JM, Rouseff RL. A comparison of citrus blossom volatiles. Phytochemistry. 2009;70(11-12):1428-34.

17.Radłowski M. Proteolytic enzymes from generative organs of flowering plants (Angiospermae). J Appl Genet. 2005;46(3):24757.

18.Mazorra-Manzano MA, Moreno-Hernandez JM, Ramirez-Suarez JC, et al. Sour Orange Citrus aurantium L. flowers: A new vegetable source of milk-clotting proteases. LWT-Food Sci Technol. 2013;54(2): 325-330.

19.Oluk AC, M Güven, Hayaloglu AA. Proteolysis texture and microstructure of low-fat Tulum cheese affected by exopolysaccharide- producing cultures during ripening. Int. J. Food Sci. Technol. 2014;49:435-443.

20.Romeih EA, Moe KM, Skeie S. The influence of fat globule membrane material on the microstructure of low-fat Cheddar cheese. Int. Dairy J. 2012;26:66-72.

21.Amelia I, Drake M, Nelson B, et al. A new method for the production of low-fat Cheddar cheese. J Dairy Sci. 2013;96(8):4870-84.

22.Di Cagno R, De Pasquale I, De Angelis M, et al. Use of microparticulated whey protein concentrate, exopolysaccharide-producing Streptococcus thermophilus, and adjunct cultures for making lowfat Italian Caciotta-type cheese. J Dairy Sci. 2014;97(1):72-84.

23.Khanal BKS, Bhandari B, Prakash S, et al. Modifying textural and microstructural properties of low fat Cheddar cheese using sodium alginate. Food Hydrocoll. 2018;83:97-108.

24.Dabour N, Kheadr E, Benhamou N, et al. Improvement of texture and structure of reducedfat Cheddar cheese by exopolysaccharideproducing lactococci. J Dairy Sci. 2006;89(1):95110.

25.Jimenez-Flores R, Yee J. Low tempetature hard cheeses and semi-hard washed cheeses. In B. C. Weimer (Ed.). Improving the flavor of cheese. 2007;444-473.

26.Lopez C, Camier B, Gassi JY. Development of the milk fat microstructure during the manufacture and ripening of Emmental cheese observed by confocal laser scanning microscopy. International Dairy Journal. 2007;17(3), 235-247.

27.Walstra P, Woters Jan TM, Geurts TJ. Dairy Science and technology. $2^{\text {nd }}$ Ed. CRC Press Boca Raton FL, USA. 2006;744-773.

28.O'Mahony JA, Sheehan EM, Delahunty CM, et al. Lipolysis and sensory characteristics of Cheddar cheeses ripened using different temperature-time treatments. Le Lait. 2005;86(1): 59-72.

29.Singh TK, Drake MA, Cadwallader KR. Flavor of Cheddar cheese: a chemical and sensory perspective. Compr. Rev. Food Sci. Food Saf. 2003;2:166-189.

30.Benatar JR, Sidhu K, Stewart RA. Effects of high and low fat dairy food on cardio-metabolic risk factors: a meta-analysis of randomized studies. PLoS One. 2013;8(10):e76480.

31.De Goede J, Geleijnse JM, Ding EL, et al. Effect of cheese consumption on blood lipids: a systematic review and meta-analysis of randomized controlled trials. Nutr Rev. 2015;73(5):259-75.

32.Livingstone KM, Lovegrove JA, Givens DI. The impact of substituting SFA in dairy products with MUFA or PUFA on CVD risk: evidence from human intervention studies. Nutr Res Rev. 2012;25(2):193-206.

33. Lovegrove JA, Givens DI. Dairy food products: good or bad for cardiometabolic disease? Nutr Res Rev. 2016;29(2):249-267. 
34. Markey O, Vasilopoulou D, Kliem KE, et al. Plasma phospholipid fatty acid profile confirms compliance to a novel saturated fat-reduced, monounsaturated fat-enriched dairy product intervention in adults at moderate cardiovascular risk: a randomized controlled trial. Nutr J. 2017;16(1):33.

35. Wang J, Wu T, Fang X, et al. Manufacture of low-fat Cheddar cheese by exopolysaccharideproducing Lactobacillus plantarum JLK0142 and its functional properties. J Dairy Sci. 2019;102(5):3825-3838.

36.Lombardi J, Ciocia F, Uniacke-Lowe T, et al. Application of an Enzymatic Extract from Aspergillus niger as Coagulant for Cheddar Cheese Manufacture. Brazilian Archives of Biology and Technology. 2019;62. 